\title{
Pembelajaran Daring Dengan Keterbatasan Akses Internet di Pelosok Desa Era Covid-19 (Studi Kasus SMK Telkom Medan)
}

\author{
Jamaludin \\ Teknik Informatika, Politeknik Ganesha, Medan, Indonesia \\ Email: jamaludinmedan@gmail.com
}

\begin{abstract}
This study aims to find out the problems experienced by some students, especially those who live in remote villages related to limited internet network access during the Covid-19 pandemic. This research uses the activity method with continuing education. The subjects sampled in the study were four students of SMK Telkom Medan who live in four different villages with different conditions of limited internet network access. Based on the findings of the researchers, even though they face obstacles in online learning, they are still enthusiastic and struggle to be able to continue online learning despite their limitations. This is very different for students who live in cities with complete facilities but their learning motivation is very low. Then the online activities of some students who had online problems in remote villages were documented and made videos which were then published through social media and online media so that they hoped to generate learning motivation for other students who live with adequate facilities and infrastructure.
\end{abstract}

Keywords: Covid-19, Online Obstacles, Remote Villages, Online Media, Social Media

\begin{abstract}
Abstrak
Penelitian ini bertujuan untuk mengetahui problematika yang dialami beberapa siswa khususnya yang tinggal di pelosok desa terkait dengan keterbatasan akses jaringan internet saat pandemi Covid-19. Penelitian ini menggunakan metode kegiatan dengan pendidikan berkelanjutan. Subjek yang dijadikan sampel dalam penelitian sebanyak empat orang siswa SMK Telkom Medan yang tinggal di tempat pelosok desa yang berbeda dengan kondisi keterbatasan akses jaringan internet yang berbeda pula. Berdasarkan hasil temuan peneliti, walaupun mereka mendapat kendala dalam belajar daring, namun mereka tetap bersemangat dan berjuang untuk bisa melanjutkan pembelajaran daring walau dalam keterbatasan. Hal ini sungguh sangat berbeda bagi siswa yang tinggal di kota dengan fasilitas yang lengkap namun motivasi belajar mereka sangat rendah. Kemudian kegiatan daring dari beberapa siswa yang mendapat kendala daring di pelosok desa tersebut didokumentasikan dan dibuat videonya selanjutnya dipublikasikan melalui media sosial dan media online sehingga harapannya bisa membangkitkan motivasi belajar bagi siswa lain yang tinggal dengan sarana dan prasarana yang memadai.
\end{abstract}

Kata Kunci: Covid-19, kendala daring, pelosok desa, media online, media sosial

\section{A. PENDAHULUAN}

Pandemi Covid-19 yang sedang mewabah di seluruh dunia termasuk Indonesia, berdampak kepada seluruh sektor kehidupan manusia. Tidak hanya berkaitan dengan sektor kesehatan, tetapi juga ekonomi, sosial, agama, bahkan dunia pendidikan. Pandemi ini telah mengubah pola pendidikan yang selama ini bersifat tatap muka menjadi daring dengan memanfaatkan teknologi yang ada. Perubahan itu mengharuskan kita untuk beradaptasi dan bertindak serta selalu belajar dari sesuatu yang baru.
Disamping kelebihannya, pembelajaran daring era pandemi Covid-19 berdampak negatif, hal ini seperti diutarakan oleh Wahana Visi Indonesia yang melakukan survey terhadap 3.000 anak pada tanggal 2- 21 April 2020 dan mengungkapkan bahwa virus Corona membawa pengaruh emosional terhadap siswa. Banyak peserta didik yang merasa terisolasi dari relasi pertemanan, situasi yang membosankan di rumah, sampai ketegangan hubungan keluarga karena beban ekonomi yang meningkat selama pandemi COVID19.(Fey, 2020) 
Dalam penelitian dua tahun terakhir saat pandemi Covid-19, banyak para peneliti membahas permasalahan yang berkaitan dengan mewabahnya Covid-19 khususnya terkait dengan pendidikan. Seperti hasil penelitian sebuah lembaga bernama Inovasi (2020) yang melakukan penelitian untuk mengetahui penerapan kebijakan belajar daring di Indonesia. Pada awal bulan April 2020, Inovasi mensurvei sekitar 300 responden orang tua siswa sekolah dasar di 18 kabupaten dan kota di provinsi Nusa Tenggara Timur, Nusa Tenggara Barat, Kalimantan Utara, dan Jawa Timur. Dari hasil survey menunjukkan adanya ketimpangan dalam menggunakan media pembelajaran antara anak dari keluarga ekonomi mampu dan kurang mampu. Inovasi menemukan bahwa responden yang menyatakan anak mereka belajar dengan menggunakan media online hanya sekitar $28 \%$ dan responden menyatakan anak belajar dengan menggunakan media offline sebesar $66 \%$ dan sisanya tidak ada bahan yang diberikan oleh guru sebesar 6\%. Ditinjau dari provinsi, semakin terpencil provinsi tersebut maka semakin kecil persentase siswa yang mendapatkan pembelajaran daring . Di Jawa Timur, responden yang menyatakan anak mereka mendapatkan pembelajaran daring sebesar 40\%. Di Nusa Tenggara Barat pembelajaran daring kurang dari $10 \%$ dan di Nusa Tenggara Timur kurang dari $5 \%$. Selebihnya melalui offline buku dan lembar kerja siswa.

Grafik persentase metode belajar daring dibanding belajar tatap muka selama belajar di rumah menurut Inovasi, bisa dilihat pada gambar 1

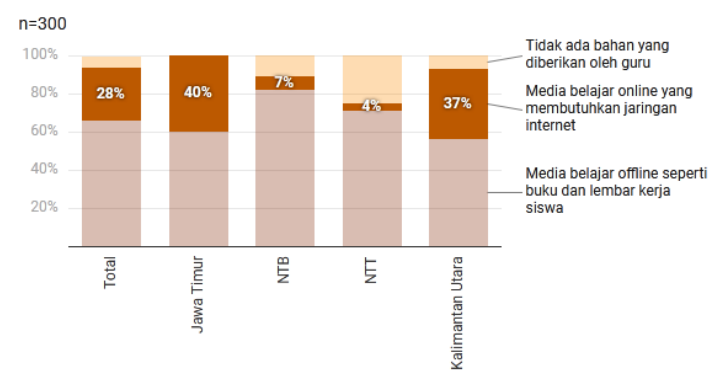

Gambar 1. Grafik persentase menggunakan media belajar daring selama belajar di rumah(Inovasi, 2020)

Dari hasil penelitian di atas, bahwa salah satu kendala pembelajaran daring khususnya di pelosok desa adalah koneksi jaringan akses internet yang tidak merata di seluruh Indonesia, hal ini diperkuat oleh pernyataan Kemendikbud. Menurut Kemendikbud (Kemendikbud, 2020), pelaksanaan pembelajaran daring di Indonesia era pandemik Covid-19 khususnya di beberapa kota besar di Indonesia terutama di kalangan ekonomi mampu dapat berjalan dengan baik karena ketersediaan perangkat, fasilitas, sarana dan prasarananya sangat mendukung. Keterbatasan kepemilikan perangkat komputer atau laptop dan juga koneksi internet, merupakan kendala utama yang berdampak pada tidak meratanya pelaksanaan pembelajaran daring khususnya di pelosok-pelosok desa terpencil yang umumnya tingkat ekonomi menengah kebawah. Dengan adanya virus Corona juga berdampak kepada tingkat emosional anak, hal ini juga menghambat proses pembelajaran di kalangan peserta didik.

SMK Telkom Medan merupakan salah satu institusi pendidikan kejuruan di Sumatera Utara yang digemari banyak siswa yang tersebar dari mulai kota sampai ke pelosok desa, tidak hanya di dalam bahkan sampai di luar provinsi Sumatera Utara. Dampak negatif dari daring tidak hanya dialami oleh sebagian besar institusi pendidikan, SMK Telkom Medan juga merasakan dampak dari pelaksanaan daring di era Covid-19 tersebut. Minimnya minat belajar siswa dan rendahnya hasil nilai belajar, merupakan salah satu dampak negatif dari pembelajaran daring tersebut. Tentunya ini menjadi masalah baik untuk siswa dan orang tua siswa maupun bagi pihak sekolah. Namun dibalik permasalahan tersebut, ada beberapa siswa yang tinggal di pelosok desa yang mereka berjuang dan harus berpindah hanya ingin mendapatkan akses internet agar bisa melanjutkan pembelajaran daring. Tentunya ini menjadi contoh yang baik apabila didokumentasikan dan diperlihatkan kepada siswa-siswi yang lain yang mana mereka mendapatkan fasilitas yang cukup baik untuk mendukung pembelajaran daring, namun motivasi belajar mereka begitu rendah bila dibanding dengan siswa yang tinggal di pelosok desa.

Berdasarkan latar belakang masalah diatas maka peneliti merumuskan masalah dalam penelitian ini adalah terbatasnya jaringan akses internet di pelosok desa yang menyebabkan terkendalanya pembelajaran daring beberapa siswa yang mereka harus berjuang walau dalam keterbatasan, dan rendahnya motivasi belajar yang tinggal di kota walau dengan sarana dan prasarana yang memadai.

\section{B. PELAKSANAAN DAN METODE}

Penelitian dilaksanakan pada SMK Telkom Medan yang berlokasi di Jl. Jamin Ginting Km. 11,1 No. 9C Simpang Selayang Kec. Medan Tuntungan Kota Medan.

\section{a. Teknik Pengumpulan Data}

Teknik pengumpulan data yang dilakukan dalam melakukan penelitian ini adalah : (Jamaludin dan Romindo, 2019)

a) Observasi,

Kegiatan mengamati langsung terhadap kegiatan yang sedang terjadi, untuk 
mendapatkan data-data yang lengkap dan akurat. Pada metode observasi ini peneliti melakukan pengamatan langsung di SMK Telkom Medan untuk memperoleh gambaran operasional yang berlangsung di sekolah tersebut.

b) Wawancara,

Kegiatan ini dilakukan dengan berkomunikasi secara langsung dan tidak langsung melalui smartphone dan media online seperti Google Meet. Peneliti melakukan tanya jawab kepada kepala sekolah, para guru khususnya dan para siswa yang mendapat kendala daring di daerah pelosok desa serta siswa yang motivasi belajarnya rendah di sekitar sekolah, untuk memperoleh informasi yang lengkap.

c) Studi Pustaka,

Metode ini membantu peneliti untuk mendapatkan referensi yang mendukung melalui buku, jurnal, seminar dan sumber lain yang bersumber dari internet.

\section{b. Metode Kegiatan Penelitian}

Kegiatan penelitian yang dilakukan dalam penelitian ini menggunakan metode pendidikan berkelanjutan.

Adapun langkah-langkah dalam penelitian ini adalah :

a). Perencanaan

Langkah ini merupakan awal dari proses kegiatan untuk mempersiapkan proses selanjutnya. Pada proses ini, dimulai survei ke lokasi mitra untuk melihat secara langsung kondisi yang sebenarnya. Dari survei ditemukan masalah yang dihadapi mitra adalah keterbatasan daring beberapa siswa khususnya yang tinggal di pelosok desa dan masalah rendahnya motivasi belajar siswa yang tinggal di kota saat pandemi Covid-19.

\section{b). Pelaksanaan}

Penelitian ini dilaksanakan selama satu bulan mulai dari tanggal 09 September 2020 sampai 09 Oktober 2020. Selama pelaksanaan penelitian ada dua kegiatan yang dilakukan yaitu membuat video keterbatasan daring di pelosok desa dan membuat pertemuan antara beberapa siswa yang mendapat kendala daring dengan wali kelas mereka

c. Evaluasi

Kegiatan yang sudah dilaksanakan dievaluasi tingkat keberhasilannya. Kemudian hasil kegiatan dipublikasi dalam bentuk jurnal pengabdian dan media online.

Adapun diagram proses pelaksanaan penelitian bisa dilihat pada skema seperti gambar 2 .

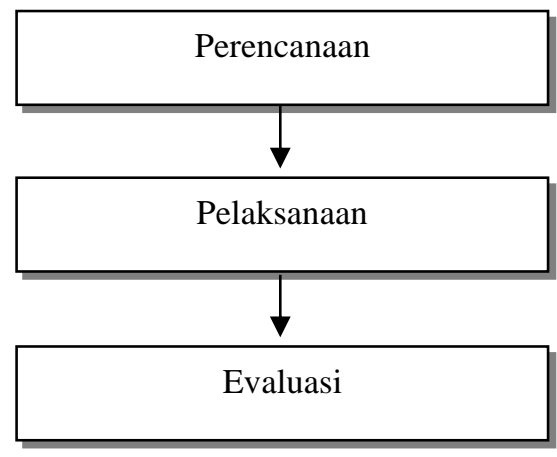

Gambar 2. Diagram langkah-langkah dalam penelitian

\section{c. Proses Pembuatan Video}

Adapun langkah-langkah dalam melakukan proses pembuatan video siswa yang mendapat kendala daring di pelosok desa adalah sebagai berikut :

\section{Shooting}

Proses terekamnya objek-objek oleh kamera video, baik analog maupun digital. Pengambilan gambar dilakukan untuk mendapatkan bahan-bahan klip (footage).

Pengambilan gambar atau video dilakukan oleh setiap siswa di tempat masing-masing yang mendapat kendala daring. Pada proses ini, mereka merekam mulai dari awal keberangkatan menuju lokasi daring sampai tempat mereka mendapat akses internet kemudian, proses daring dan penutup.

Kemudian hasil rekaman video tersebut dikirim ke peneliti melalui WhatsApp. Setidaknya ada empat siswa yang merekam kegiatan mereka dengan cara-cara yang berbeda, diantaranya dengan memanjat pohon, mendaki sebuah bukit, menuju tower dengan medan yang cukup sulit dan menaiki atap rumah

\section{Capturing}

Merupakan proses pemindahan hasil rekaman dari kamera video analog atau digital ke dalam harddisk komputer.

Hasil rekaman gambar atau video yang dikirimkan oleh siswa kemudian dipindahkan ke dalam harddisk komputer atau laptop untuk dilakukan proses editing

3. Editing

Merupakan bagian utama dalam membuat sebuah klip. Bagian ini merupakan proses perangkaian klip, pengaturan durasi, membuang klip yang tidak diperlukan, memberikan musik 
latar, memberikan title, memberikan transisi, dan memberikan efek-efek lainnya.

Editing klip video dilakukan untuk menggabungkan beberapa video atau gambar dengan penambahan pengaturan fitur-fitur seperti warna, text, transisi, atau suara sehingga menjadi hasil editing video yang menarik. Adapun software yang digunakan dalam mengedit editing video menggunakan Ulead Video Studio 10.

\section{Finishing}

Output akhir atau hasil akhir dari proses editing bisa berupa CD/DVD atau juga video tape.

Adapun diagram proses dalam pembuatan video bisa dilihat pada skema seperti gambar 3 .

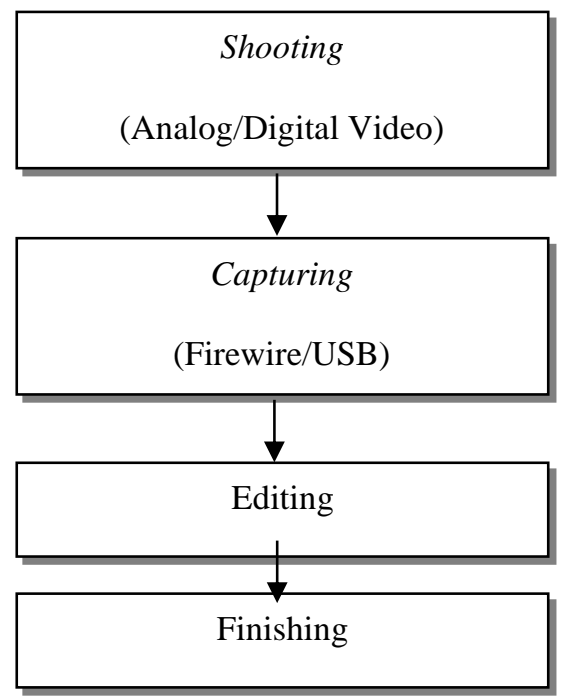

Gambar 3. Diagram proses dalam pembuatan video

Dalam membuat video keterbatasan daring di pelosok desa menggunakan software aplikasi Ulead Video Studio 10. Kelebihan program Ulead Video Studio 10 adalah dapat menyimpan video yang direkam ke dalam harddisk langsung dalam format MPEG VCD, atau DVD. Dengan demikian user tidak perlu melakukan proses konversi file Avi ke Mpeg, dengan syarat pada saat merekam harus dilakukan dengan sistem digital.

Dalam membuat video keterbatasan daring di pelosok desa menggunakan software aplikasi Ulead Video Studio 10 seperti pada gambar 4. Kelebihan program Ulead Video Studio 10 adalah dapat menyimpan video yang direkam ke dalam harddisk langsung dalam format MPEG VCD, atau DVD. Dengan demikian user tidak perlu melakukan proses konversi file Avi ke Mpeg, dengan syarat pada saat merekam harus dilakukan dengan sistem digital.

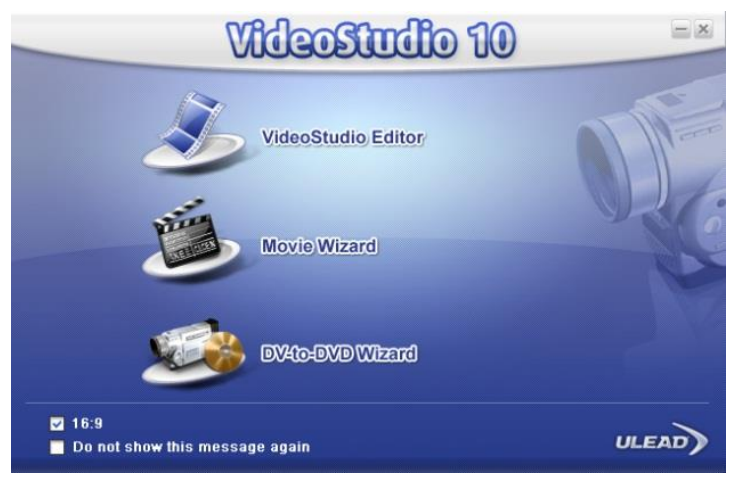

Gambar 4. Tampilan Ulead Video Studio Versi 10

Spesifikasi perangkat laptop yang digunakan untuk membuat video tersebut adalah :

- Mikroprosesor Intel Core I3 2,27 GHz

- RAM 2 GB

- Hard disk $250 \mathrm{~GB}$

Adapun spesifikasi laptop tersebut bisa dilihat pada gambar 5 .

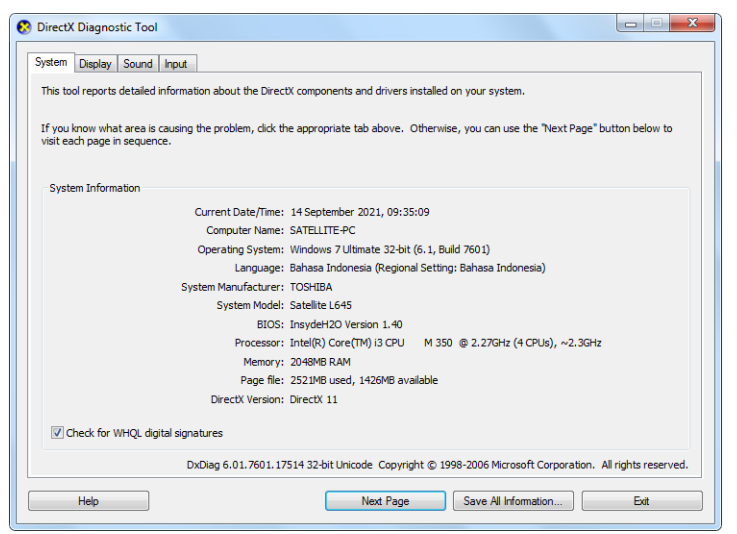

Gambar 5. Spesifikasi perangkat laptop

Adapun langkah-langkah pada proses editing video adalah sebagai berikut :

1) Hubungkan seluruh peralatan dengan benar. Bila user menggunakan Windows 7 dan sistem digital, begitu peralatan terhubung dan source digital dalam keadaan ON maka secara otomatis Windows akan memanggil program capturing video. Seperti tampilan pada gambar 6. 


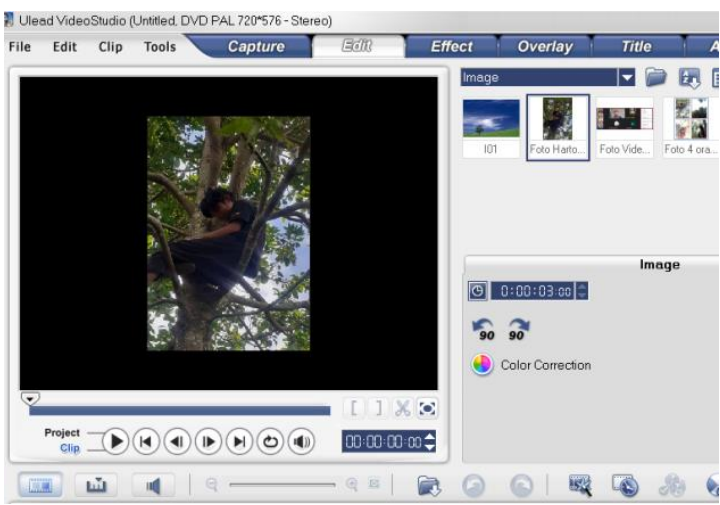

Gambar 6. Tampilan input image ke lembar kerja Ulead Video Studio

2) Bila menggunakan sistem analog, setelah langkah nomor 1 di atas selanjutnya adalah buka aplikasi ini.

3) Pilih Tab Capture

4) Pilih Format penyimpanan yang dikehendaki (PAL DV, NTSC DV, VCD, atau DVD).

5) Tentukan di direktori mana file akan disimpan.

6) Tekan tombol Capture Video untuk memulai perekaman. Bila menggunakan sistem digital maka secara otomatis kamera akan memutar kaset begitu tombol record di komputer ditekan.

7) Bila menggunakan sistem analog, tekan tombol PLAY pada kamera atau sumber lainnya.

8) Tekan tombol stop capture bila telah selesai

\section{HASIL DAN PEMBAHASAN}

Ada dua hasil kegiatan yang dilakukan dalam selama penelitian ini yaitu

a. Kegiatan membuat pertemuan beberapa siswa yang mendapat kendala daring dengan wali kelas menggunakan media online melalui Google meet.

Kendala daring yang dialami beberapa siswa yang mendapat kendala daring di pelosok desa, menyebabkan terputusnya komunikasi antara mereka dengan wali kelas mereka. Peneliti mencoba menginisiasi pertemuan antara wali kelas dan siswa yang mendapat kendala daring di pelosok desa melalui teknologi dengan menggunakan Google Meet.

Seperti yang sudah dipublikasikan oleh Jamaludin (2020) melalui media online infoMu bahwa pertemuan secara daring melalui Google Meet terlaksana tanggal 2 Oktober 2020. Acara tersebut juga dihadiri oleh Drs. Muhammad Yusuf, S.Kom Waka Kesiswaan yang mewakili pihak manajemen, kemudian wali kelas yang berhadir diantaranya $\mathrm{Hj}$. Tirodiah Harahap, S.Ag sebagai wali kelas XITJA2 dan Poniman, S.Sos.,MM sebagai wali kelas XI TKJ2. Kemudian siswa SMK Telkom Medan yang berhasil mengikuti acara virtual melalui Google Meet tersebut adalah Harto Wisno Tondang siswa kelas XI-TJA2, Yamagitsu siswa kelas XI-TJA2, Syara Ketaren siswa kelas XITKJ3 dan Rifky Syarif Hidayat siswa kelas XITKJ1.

Acara video conference ini dimulai jam 13.30 Wib dibuka oleh Jamaludin,M.Kom kemudian dilanjutkan kata sambutan dari Drs. Muhammad Yusuf, S.Kom sebagai mewakili manajemen SMK Telkom Medan yang mengapresiasi siswa-siswa yang sudah berusaha untuk tetap belajar walau medan yang ditempuh cukup sulit untuk mendapatkan akses internet. Kemudian masingmasing anak menceritakan kendala yang terjadi di tempat masing-masing ke wali kelas mereka dan terjadi diskusi diantara mereka.

Proses mediasi antara siswa dan wali kelas menggunakan Google Meet, bisa dilihat pada gambar 7.

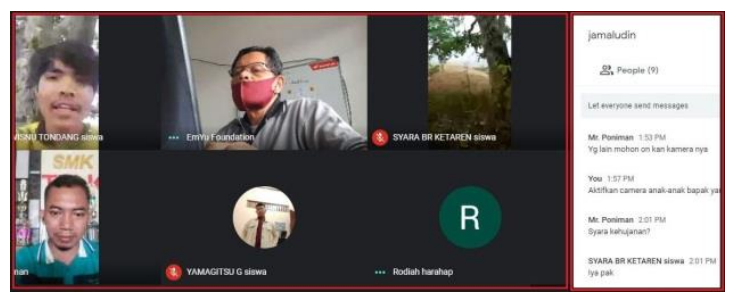

Gambar 7. Proses mediasi antara siswa dan wali kelas menggunakan Google Meet

b. Kegiatan membuat video edukasi bagi beberapa siswa yang mendapat kendala daring di pelosok desa

Hasil video kendala daring di pelosok desa yang dibuat melalui software aplikasi Ulead Video Studio 10, kemudian dipublikasikan ke Youtube sehingga bisa dilihat banyak orang. Adapun hasil publikasi bisa lihat pada gambar 8

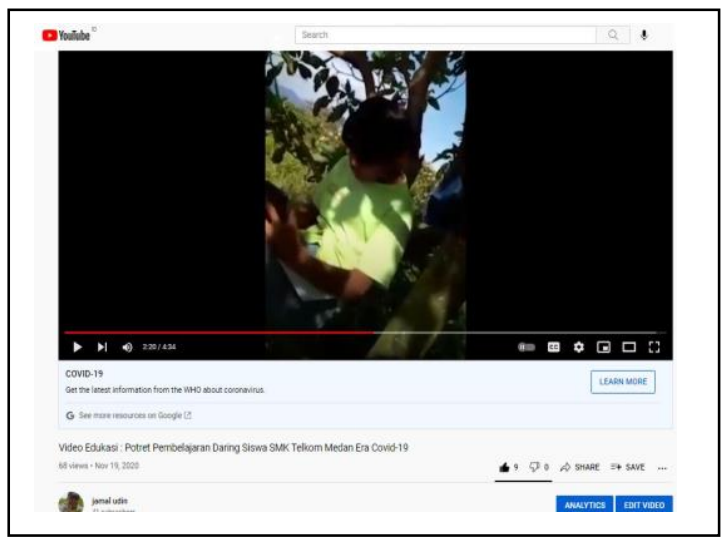



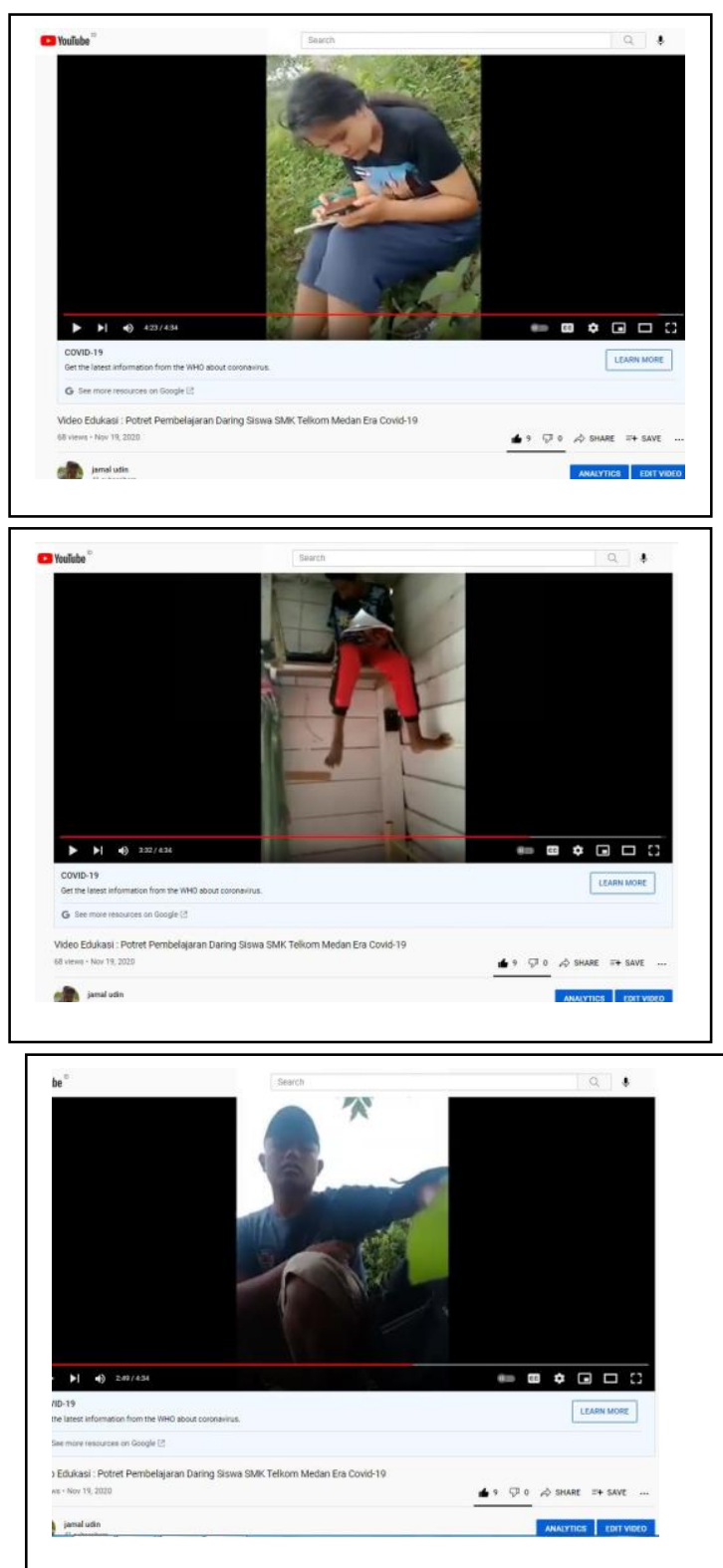

Gambar 8. Video keterbatasan daring di pelosok desa menggambarkan beberapa siswa SMK Telkom

Video keterbatasan daring di pelosok desa menggambarkan beberapa siswa SMK Telkom Medan yang tinggal di pelosok desa yang mereka berjuang untuk mendapat akses internet. Ada 4 orang siswa yang berhasil ditemui diantaranya adalah Harto Wisno Tondang siswa kelas XI-TJA2, Yamagitsu siswa kelas XI-TJA2, Syara Ketaren siswa kelas XI-TKJ3 dan Rifky Syarif Hidayat siswa kelas XI-TKJ1.

Keterbatasan siswa dalam melakukan daring bervariasi sesuai dengan kondisi daerah masingmasing, seperti ada siswa sedang berada di atas pohon setinggi 6 meter, ada juga sedang berada di suatu tempat yang harus berdekatan dengan tower yang ditempuh dengan medan yang cukup sulit, berada di tempat yang dirancang untuk belajar dengan ketinggian 3 meter di sekitar rumahnya, bahkan ada juga salah satu siswi berada di Gunung Pola. Walaupun dalam kondisi yang terbatas mereka tidak putus asa dan terus berjuang supaya bisa ikut melanjutkan daring

\section{PENUTUP}

\section{a. Simpulan}

Berdasarkan hasil analisis data, pengujian hasil penelitian, dan pembahasan, dapat disimpulkan bahwa salah satu kendala belajar daring di pelosok daerah adalah keterbatasan akses jaringan internet, namun mereka tetap bersemangat dan berjuang untuk bisa melanjutkan pembelajaran daring walau dalam keterbatasan.

\section{b. Saran}

Saran yang bisa disampaikan bahwa penelitian ini dapat digunakan sebagai referensi untuk penelitian selanjutnya guna mengembangkan penelitian ini untuk mengetahui pengaruh video keterbatasan daring di pelosok desa terhadap motivasi belajar siswa di era pandemi Covid-19

\section{Ucapan Terima Kasih}

Terima kasih kepada kepala sekolah SMK Telkom Medan, melalui surat no. 039/SMKTEL/E11/IX/2020 perihal surat pernyataan kesediaan bekerjasama dari mitra dalam pelaksanaan pengabdian kepada masyarakat, memberikan kesempatan kepada peneliti untuk melakukan penelitian di sekolah tersebut. Ucapan terima kasih juga kepada para guru yang telah bekerja sama sehingga pelaksanaan penelitian ini berjalan sukses

\section{E. DAFTAR PUSTAKA}

Fey (2020) New Normal Sekolah, Antara Sif Belajar dan Modifikasi Materi, CNN Indonesia. Tersedia pada: https://www.cnnindonesia.com/nasional/2020 0520150450-20-505344/new-normal-sekolahantara-sif-belajar-dan-modifikasi-materi.

Inovasi (2020) Riset dampak COVID-19: potret gap akses online 'Belajar dari Rumah' dari 4 provinsi. Tersedia pada: https://theconversation.com/riset-dampakcovid-19-potret-gap-akses-online-belajardari-rumah-dari-4-provinsi-136534.

Jamaludin (2020) Belajar Daring di SMK Telkom Medan, Akhirnya, Google Meet Mempertemukan Mereka, infomu. Tersedia pada: https://infomu.co/2020/10/23/belajardaring-di-smk-telkom-medan-akhirnyagoogle-meet-mempertemukan-mereka/. 
Jamaludin, J. dan Romindo, R. (2019) "Sistem Informasi Akademik Berbasis Web Menggunakan Metode Waterfall Pada SMA Kemala Bhayangkari I Medan," in Semantika. Medan: Politeknik Ganesha Medan, hal. 1727. Tersedia pada: https://semantika.polgan.ac.id/index.php/Sem antika/article/view/54.
Kemendikbud (2020) Panduan Penyelenggaraan Pembelajaran pada Tahun Ajaran dan Tahun Akademik Baru di Masa Covid-19. Tersedia pada:

https://www.kemdikbud.go.id/main/blog/202 0/06/panduan-penyelenggaraanpembelajaran-pada-tahun-ajaran-dan-tahunakademik-baru-di-masa-covid19. 